\title{
GROUNDWATER GEOCHEMISTRY OF RROGOZHINA AQUIFER (WESTERN ALBANIA)
}

\author{
Luzati S. ${ }^{1}$, Beqiraj A. ${ }^{1}$ and Jaupaj O. $^{2}$ \\ ${ }^{\text {I}}$ Polytechnic University of Tirana, Faculty of Geology and Mines, Rruga Elbasani, Tirana, \\ Albania \\ ${ }^{2}$ Geological Survey of Albania, Rruga Kavaja, 153, Tirana, Albania
}

\begin{abstract}
This paper aims to make a geochemical characterization of the groundwater of Rrogozhina aquifer which extends over the Albanian pre-Adriatic depression covering a surface of $2100 \mathrm{~km}^{2}$. It is a multilayered aquifer consisting of intercalations between water-bearing Pliocene sandstone and conglomerate with impermeable clay layers. This aquifer occurs under typically artesian conditions because of its impermeable clay basement and semi-impermeable Quaternary cover. The groundwater shows variable geochemical composition due to different mineralogical composition of its medium and vast extension of the aquifer. However, the mainly magmatic - carbonatic mineralogical composition of the water - bearing sandstones and conglomerates has determined a geochemical composition of groundwater consisting mostly of $\mathrm{HCO}_{3}-\mathrm{Mg}-\mathrm{Ca}$ hydrochemical groundwater type. Dissolution of minerals seems to be the major geochemical processes in the formation of the groundwater composition. The above mainly magmatic composition of sandstones and conglomerates is also responsable for the high content of iron in the grounwater of this aquifer. Iron content is higher in sandstone related groundwater where the silt fraction is mainly composed by ironbearing minerals such as magnetite, epidote, granate, sphene, amphibole and pyroxene. The general mineralization and general hardness of groundwater range from 500 to $800 \mathrm{mg} / \mathrm{l}$ and from 11 to $25^{\circ} \mathrm{dH}$, respectively.

Keywords: aquifer, groundwater, geochemical composition, mineralogical composition.
\end{abstract}

\section{Introduction}

The Pliocene aquifer of Rrogozhina spread out over the Albanian pre-Adriatic depression and extends from Shkodra in the north to Vlora in the south. It is mainly composed of sandstone and conglomerate intercalated with impermeable clay layers. The basement of the aquifer consists of impermeable clays, whereas the Quaternary formations represent its younger cover (Hyseni, 1995). This later, that is present only over the plain terrains of the aquifer extension, consists of clay, sandy clay, silt, silty sand, sand, gravel and pebbles. The Rrogozhina aquifer is a multilayered aquifer that occurs under typically artesian conditions (Eftimi, 1984). Based on its water potential this aquifer represents the second one after the Quaternary alluvial aquifers in Albania. The abundant hydrogeological drillings found that the sandstone and conglomerate layers are rich in groundwater to different extent. The permeability of the aquifer is extremely variable showing irregular variations in both vertical and horizontal directions. Such a variable permeability is due to variable lithology, heterogeneous particle size composition and different extent of compactness of the water-bearing layers. Beqiraj et al. (2007), found that the low values of General Mineralization do not fit at all the corresponding high $\mathrm{K}$ values as it could be expected in the case of a heterogeneous aquifer. With 
respect to chemical composition the groundwater of Rrogozhina aquifer, its water mostly belong to HCO3-Mg-Ca hydrochemical type. The above composition is due to the mainly magmatic carbonatic mineralogical composition of the water - bearing sandstones and conglomerates. The above mainly magmatic composition of sandstones and conglomerates is responsable for the high content of iron in the grounwater of this aquifer, as well. Both the hydrochemistry of the grounwater and its iron content show variable values because of heterogeneous mineralogical and lithological composition of the water-bearing sandstones and conglomerates.

\section{Materials and methods}

Over 50 water samples were taken from shallow (up to $20 \mathrm{~m}$ deep) wells drilled over the outcrops o f water-bearing conglomerates and sandstones and from deeper wells $(20-150 \mathrm{~m})$ drilled in valley, b ut only 13 samples were selected for the purpose of this paper. Water for chemical analysis was dir ectly sampled in the artesian wells, while in semi-artesian ones it was either pumped or using the $S$ EBA Liquid Sampler KLL-S. Chemical analysis are made in Chemical laboratory of the Geologica 1 Survey of Albania and in in the Chemical Laboratory of the Centre for Transfer of Technologies, Tirana. $\mathrm{Ca}, \mathrm{Mg}$, hardness, and $\mathrm{HCO}_{3}$ were analysed via titration; $\mathrm{Cl}$ and $\mathrm{SO}_{4}$ by photometry; $\mathrm{pH}$ an d electric conductivity by electrochemistry; TDS were calculated after electric conductivity values; $\mathrm{Fe}, \mathrm{Na}$ and $\mathrm{K}$ were analysed in AAS "PERKIN ELMER" in both flame technic 400 AANALYST and 900 AA model with graphite furnace.

\section{Geological setting}

The aquifer of Rrogozhina extends over the western pre-Adriatic depression of Albania (Figure 1) occupying a surface of $2100 \mathrm{~km}^{2}$. The water-bearing sandstones and conglomerates belong to Pilocene mollasic formations which are transgressively placed on the older formations, mainly represented by Miocene - Tortonian mollasic formations. The lower part of the Pliocene mollases consist of a mostly clay section known as Helmesi suite, whereas the upper part is represented by the coarse grain formations of the Rrogozhina suite. The geological section of this later in the southern sectors consists mainly of sandstones, whereas northward of its extension the conglomerates dominate (Eftimi, 1984; Hyseni, 1995). The Quaternary formations, that consist of clay, sandy clay, silt, silty sand, sand, gravel and pebbles, cover the Rrogozhina formations over the plain areas which belong to syncline forms of its extension. On the other hand, the outcrop of the Rrogozhina formations, that represent around 1/4 of its general extension, construct the anticline structures. The type of cement material is mainly carbonate, but the degree of lithification is very different; there are distinguished from freely to very strongly cemented sandstones and conglomerates (Eftimi, 2002). The above porous medium does not construct a continous section because of the presence of clay intercalations between coarse grain layers. The thickness of Rrogozhina suite ranges from 1000m (Rrogozhina outcrop) to 1700m in the center of the Karavasta syncline. The neotectonic movements have intensively affected the mollasic formations (Beqiraj et al., 2006).

\section{Hydrogeological features}

The Rrogozhina aquifer is important because of the vast $\left(2100 \mathrm{~km}^{2}\right)$ extension, thick (over $100 \mathrm{~m}$ ) water - bearing section and wide outcrops of the sandstones and conglomerates. On the other hand, there are a lot of rural and urban communities that habit within the territories of the aquifer extension. The Rrogozhina aquifer is a multilayered aquifer that occurs under typically artesian conditions. Its artesian character is conditioned by: i) the water-bearing sandstones and conglomerates are intercalated with impermeable clays; ii) they construct syncline forms; iii) the recharge zones have higher quota then the discharge zones. The sandstones and conglomerates show very heterogeneous permeability due to their different lithological composition, variable particle size distribution, different extent of their compactness, type of the cement, etc. As it could be seen in Figure 2 (Beqiraj et al., 2006), the conglomerates, that spread over the northern half of the Rrogozhina aquifer, have 
higher (2.56-4.0m/day) hydraulic conductivity then sandstones (2.05-3.0m/day), which spread over the southern part and that (2) the conglomerates of Durres area have the highest (4.0m/day) permeability (Eftimi, 2002). This has conditioned an extremely variable yield of the wells (Eftimi, 1984). The Rrogozhina sandstone-conglomerate aquifer is characterized by a dual porosity; the prevailing one is the fracture porosity, but inter-granular porosity is present as well.

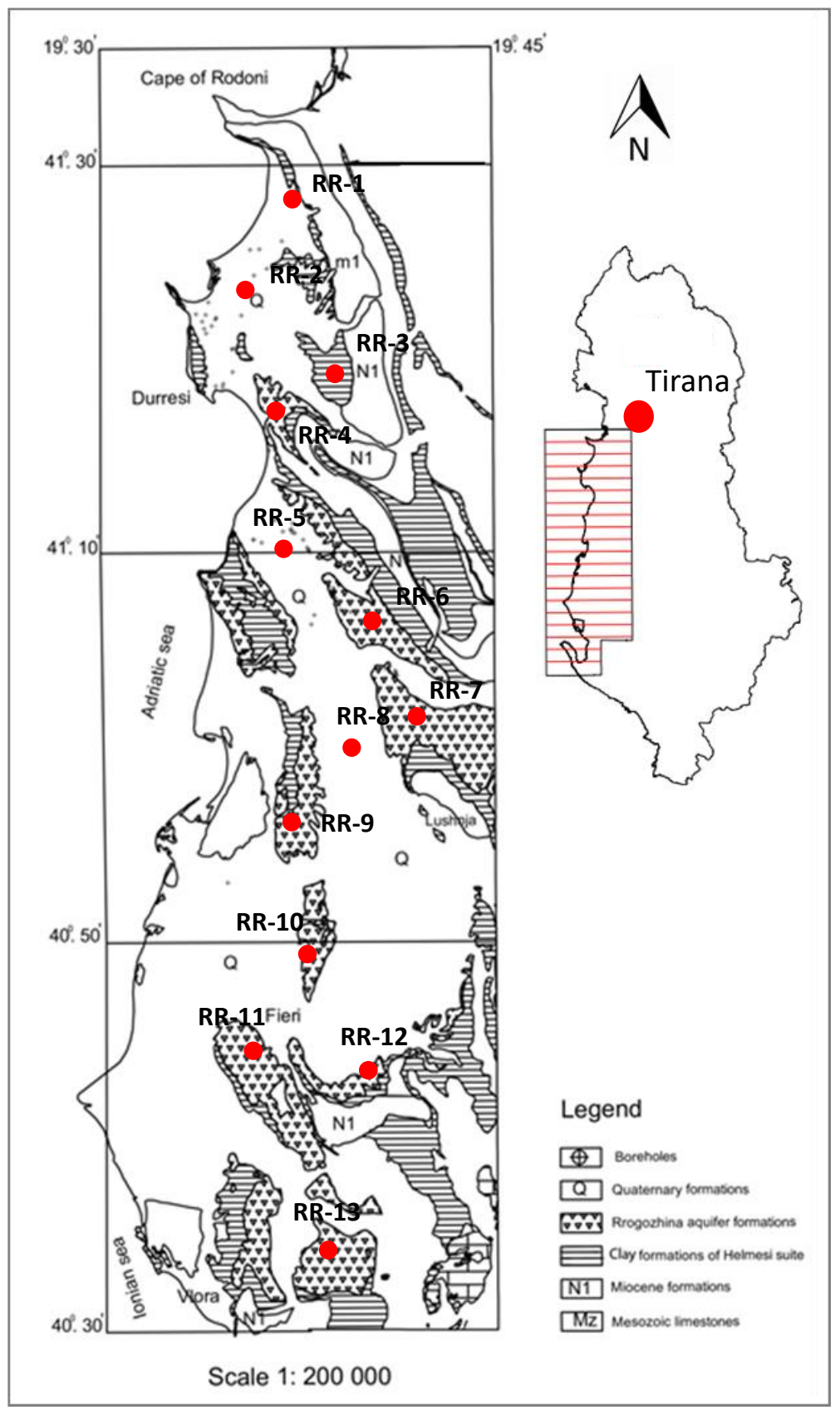

Figure 1 - Schematic geological map of Rrogozhina aquifer. 
Beside this the locally increased permeability of conglomerate aquifer layers is explained with the enlargement of the rock's fissures by the solution of carbonate cement (Eftimi, 2002). The conglomerate has higher transmissivity $($ Tmean $=78-134 \mathrm{~m} 2 /$ day $)$ then sandstone $($ Tmean $=45$ $97 \mathrm{~m} 2 /$ day) and within the conglomerate rock's areas the Durres area has distinctly higher transmissivity and the smallest variation (Eftimi, 2002).

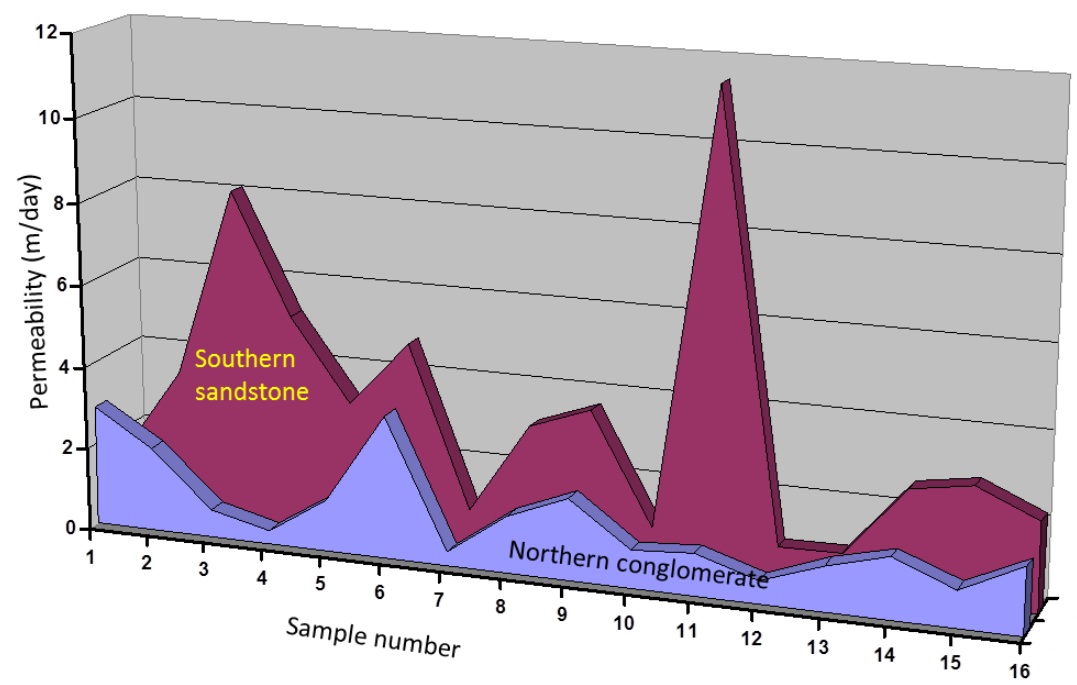

Figure 2 - Variation of hydraulic conductivity values through southern sandstone and northern conglomerate.

\section{Geochemical characteristics of groundwater}

The groundwater shows variable geochemical composition due to different mineralogical composition of its medium, vast extension of the aquifer, variable geological and hydrogeological features, relationships with boundary aquifers and seawater, relations of the tested groundwater with respect to recharge and discharge zone and possibly the depth of wells (Eftimi 1984; Beqiraj et al., 2006). However, the mainly magmatic - carbonatic mineralogical composition of the water-bearing sandstones and conglomerates has determined a geochemical composition of groundwater consisting mostly of $\mathrm{HCO}_{3}-\mathrm{Mg}$-Ca hydrochemical groundwater type (Table 1). Such a geochemical composition characterizes the groundwater of Rrogozhina aquifer as chemically immature groundwater, which mainly plots near the center of the Piper plot (Figure 3). Dissolution of minerals seems to be the major geochemical processes in the formation of the groundwater composition. Other hydrochemical types are less important and are mainly related with the Na enrichment in water through cation exchange processes between groundwater and clay formations that are more abundant over the plain extension of the aquifer. The above mainly magmatic composition of sandstones and conglomerates is also responsable for the high content of iron in the grounwater of this aquifer which occurs as Fe2+ due to the lack of O2 (Christenbury, 1990; Gruett, 1993; Postma, 1987). Iron content is higher in sandstone (Figure 4) related groundwater where the silt fraction is mainly composed by ironbearing minerals such as magnetite, epidote, granate, sphene, amphibole and pyroxene. In general, the wells are drilled down to $250 \mathrm{~m}$. The general mineralization and general hardness of groundwater pumped from the above drilled section range from 500 to $800 \mathrm{mg} / \mathrm{l}$ and from 11 to $25^{\circ} \mathrm{dH}$, respectively. At the $\mathrm{pHs}$ commonly encountered in groundwater $(\mathrm{pH}=7.0-8.5), \mathrm{HCO}_{3}{ }^{-}$is the dominant carbonate species present. In general, up to the above drilled depth, all the hydrochemical parameters of the groundwater fit the Albanian and EU limits for the potable water. In some cases, $\mathrm{NH}_{4}{ }^{+}, \mathrm{SO}_{2}, \mathrm{Cl}$, etc, are found in concentrations higher then the limits of drinking water. In the diagram (not shown) of Total Mineralization (TM) versus well depth (H) was found that groundwater can maintain TM values less that $1.0 \mathrm{mg} / \mathrm{l}$ up to a depth that ranges from 400 to $500 \mathrm{~m}$ according to the well position with respect to recharge and discharge zone (Beqiraj et al., 2006). 
Table 1 - Chemical analysis of several selected water samples.

\begin{tabular}{|c|c|c|c|c|c|c|c|c|c|c|}
\hline No.sample & $\mathrm{Na}+\mathrm{K}$ & $\mathrm{Ca}$ & $\mathrm{Mg}$ & $\mathrm{Fe}$ & $\mathrm{HCO} 3$ & $\mathrm{SO} 4$ & $\mathrm{Cl}$ & TDS & Hardness & $\mathrm{pH}$ \\
\hline $\mathrm{Rr}-1$ & 35.91 & 69.14 & 25.54 & 3 & 301.95 & 27.98 & 152.65 & 676.17 & 15.85 & 7.79 \\
\hline $\mathrm{Rr}-2$ & 93.4 & 38.1 & 52.3 & 0.3 & 346.3 & 9.9 & 156.2 & 695.5 & 17.39 & 7.95 \\
\hline Rr-3 & 35.91 & 70.14 & 38.41 & 0.55 & 285.48 & 12.76 & 203.9 & 719.65 & 18.82 & 7.6 \\
\hline $\mathrm{Rr}-4$ & 12.45 & 77.27 & 63.69 & 0.8 & 540.46 & 71.6 & 56.74 & 903.09 & 25.54 & 8.2 \\
\hline Rr-5 & 33.5 & 124 & 22.2 & 0.2 & 400.1 & 88.4 & 39.6 & 625.7 & 22.51 & 7.6 \\
\hline Rr-6 & 71.3 & 39.1 & 52 & 0.1 & 464.8 & 26.7 & 40.8 & 69.47 & 17.41 & 7.8 \\
\hline Rr-7 & 77.7 & 41.9 & 39 & 0.1 & 376.9 & 47.7 & 53.2 & 636.5 & 11.81 & 8 \\
\hline Rr-8 & 45.31 & 48.36 & 60.6 & 0.21 & 488 & 24.82 & 31.69 & 698.99 & 20.69 & 8 \\
\hline Rr-9 & 49.9 & 51.9 & 56.1 & 0.5 & 450.8 & 51 & 33.7 & 693.5 & 20.22 & 7.8 \\
\hline $\mathrm{Rr}-10$ & 45.31 & 48.36 & 60.6 & 0.21 & 488 & 31.69 & 24.82 & 698.4 & 20.69 & 8 \\
\hline $\operatorname{Rr}-11$ & 61.2 & 77 & 66 & 0.5 & 4.45 & 27.6 & 147.5 & 825.8 & 26.21 & 7.8 \\
\hline Rr-12 & 109.7 & 70.14 & 58.25 & 0.15 & 408.7 & 18.1 & 198.58 & 876.28 & 23.27 & 8.3 \\
\hline Rr-13 & 28.29 & 60.45 & 65.61 & 0.62 & 516.06 & 21.4 & 28.4 & 722.57 & 23.6 & 7.5 \\
\hline
\end{tabular}

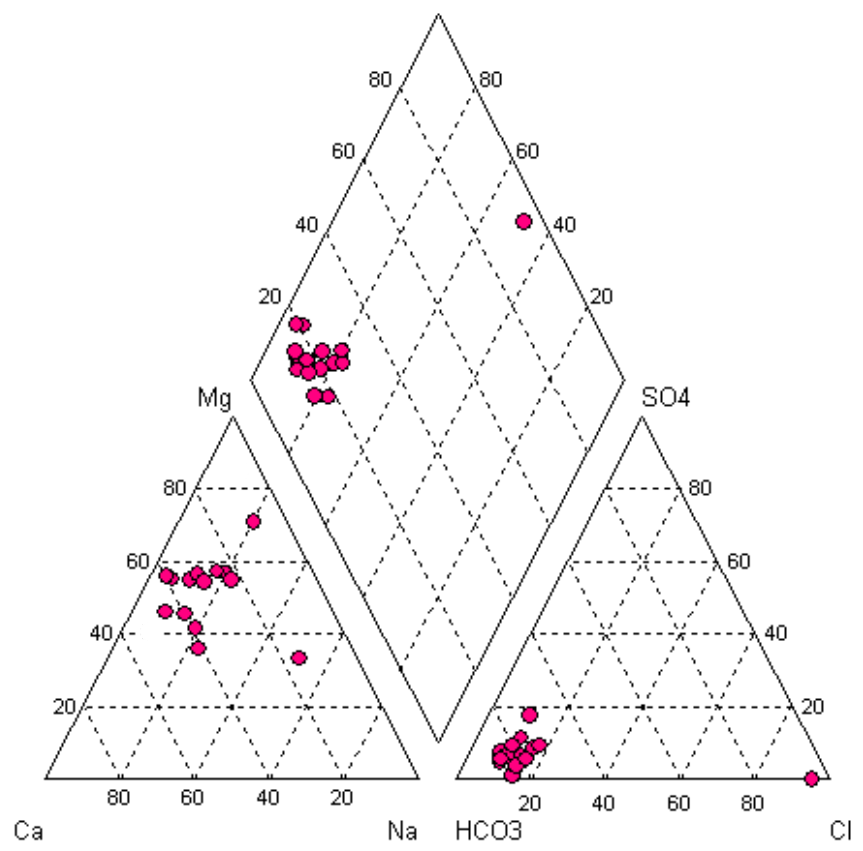

Figure 3 - Piper diagram of chemical compoasition of sampled Rrogozhina water. 


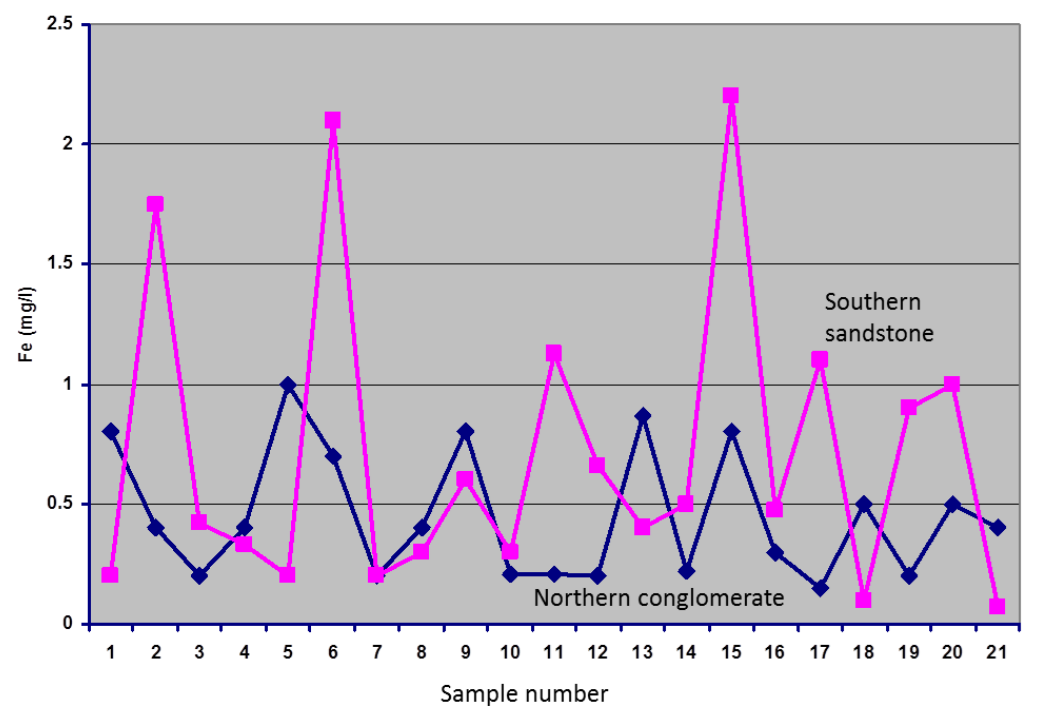

Figure 4 - Variation of iron content through southern sandstone and northern conglomerate.

\section{Conclusions}

The water-bearing sandstones and conglomerates belong to Lower Pilocene mollasic formations of the Albanian Pre-Adriatic depression and compose the sincline forms.

The Rrogozhina aquifer is a multilayered artesian aquifer that shows very high heterogeneous permeability and is characterized by a dual porosity where the fracture porosity prevails, but intergranular porosity is present as well.

The groundwater shows variable geochemical composition consisting mostly of $\mathrm{HCO} 3-\mathrm{Mg}-\mathrm{Ca}$ hydrochemical groundwater type which characterizes the groundwater of Rrogozhina aquifer as chemically immature groundwater.

The content of iron-bearing minerals such as magnetite, epidote, granate, sphene, amphibole and pyroxene in the silt fraction of sandstones and conglomerates is responsible for the high content of iron in the grounwater of this aquifer.

\section{References}

Beqiraj, A., Hyseni, A., Saraçi, M., Hoxha, I., Meshi, A., Prenjasi, E., Prela, M. and Silo, V., 2006. Assessment of ground water quality and quantity of in the Rrogozhina Acquifer as a water supply potential source for the rural zones within it, 115 pp., Agency for Research, Technology and Innovation, Albania.

Beqiraj, A., Hyseni, A., Leka, Gj. and Mata, M., 2007. Geological-structural aspects of the Rrogozhina aquifer (Albanian pre-Adriatic depression), In: abstract book of the Workshop: Management of Geomining Resources - Kosovo, 2006, 57.

Christenbury, J.H., 1990. Iron And Manganese, WQL 9. South Carolina Cooperative Extension Service, Clemson University, Clemson, SC.

Eftimi, R., 2002. Hydraulic parameters and yield of wells of sandstone-conglomerate aquifer of Rrogozhina Formation in Albania, Proceedings of 1st MEM WG Workshop on Hard Rock Hydrology, Tinos Island (Hellas).

Eftimi, R., 1984. Permeability features of Rrogozhina suite, Buletini i Shkencave Gjeologjike, 3, 57-73.

Gruett, G., 1993. Removing Problem Iron, Water Technology, 16(3), 48-51. 
Hyseni, A., 1995. Structure and geodynamic evaluation of Pliocene molasses of pre-Adriatic depression, PhD Thesis, Polytechnic University of Tirana, $175 \mathrm{pp}$.

Postma, D. and Brockenhuus-Schack, B.S., 1987. Diagenesis of iron in proglacial sand deposits of late- and post-Weichselian age, J. Sed. Petrology, 57, 1040-1053. 